\title{
Optimasi Jaringan LTE Menggunakan Metode Electrical Tilt Di Karet Kuningan
}

\author{
LTE Network Optimization Using Electrical Tilt Method At Karet Kuningan \\ Eka Purwa Laksana ${ }^{1}$, Edho Julio Aldo Restu ${ }^{2}$ \\ 1,2Teknik Elektro, Universitas Budi Luhur \\ e-mail: 1eka.purwalaksana@budiluhur.ac.id, ${ }^{2}$ edhojulio@gmail.com
}

\begin{abstract}
Abstrak
Sebagai teknologi telekomunikasi nirkabel generasi ke 4, LTE menawarkan layanan akses data berkecepatan tinggi serta latensi yang rendah. Kecepatan LTE bisa mencapai 100 Mbps pada downlink dan mencapai 50 Mbps pada uplink. Fitur ini mengakibatkan banyaknya pengguna jaringan LTE terutama di kota-kota besar yang merupakan area bisnis. Daerah Karet Kuningan menjadi salah satu contoh banyaknya pengguna pengguna LTE, namun dikarenakan lokasi tersebut dikelilingi oleh gedung-gedung tinggi perkantoran dan pemukiman padat penduduk terutama di J1. Karet Gusuran III, mengakibatkan buruknya kualitas jaringan LTE di lokasi tersebut. Pada penelitian ini dilakukan simulasi optimasi dengan menggunakan metode electrical tilt di 3 sektor dari 2 site disekitar lokasi untuk meningkatkan kualitas jaringan LTE di lokasi tersebut. Electrical tilt adalah metode untuk mengatur arah pancar antena dengan cara merubah fasa sinyal dari antena, sehingga tidak perlu dilakukan perubahan secara fisik untuk mengatur arah pancar antena. Berdasarkan hasil simulasi yang telah dilakukan, didapatkan hasil yang cukup bagus dari optimasi site KARETGUSURANDMTHL pada sektor 3. Hasil simulasi yaitu peningkatan nilai RSRP sebesar $5 \mathrm{dBm}$, peningkatan nilai SINR sebesar 0,97 dB, peningkatan nilai RSRQ sebesar 0,01 dB dan peningkatan nilai throughput dari sekitar 512 kbps menjadi sekitar 1 Mbps sampai 10 Mbps.
\end{abstract}

Kata kunci: Electrical Tilt, RSRP, RSRQ, SINR, Throughput

\begin{abstract}
As a 4th generation wireless telecommunications technology, LTE offers high-speed data access and low latency services. LTE speeds can reach 100 Mbps on the downlink and up to 50 Mbps on the uplink. This feature has resulted in many LTE network users, especially in big cities that are business areas. Karet Kuningan area is one example of the many users of LTE users, but because the location is surrounded by tall office buildings and densely populated settlements, especially on Jl. Karet Gusuran III, resulting in a poor quality of the LTE network at that location. In this research, an optimization simulation is carried out using the electrical tilt method in 3 sectors from 2 sites around the location to improve the quality of LTE networks in that location. Electrical tilt is a method for regulating the antenna transmit direction by changing the signal phase of the antenna, so there is no need to physically make changes to adjust the antenna transmit direction. Based on the results of simulations that have been carried out, a pretty good result is obtained from KARETGUSURANDMTHL site optimization in sector 3. The simulation results are an increase in RSRP value of $5 \mathrm{dBm}$, an increase in SINR value of $0.97 \mathrm{~dB}$, an increase in $R S R Q$ value of $0.01 \mathrm{~dB}$, and an increase in value throughput from around $512 \mathrm{kbps}$ to around $1 \mathrm{Mbps}$ to $10 \mathrm{Mbps}$.
\end{abstract}

Keywords: Electrical Tilt, RSRP, RSRQ, SINR, Throughput 


\section{PENDAHULUAN}

Jaringan LTE atau Long Term Evolution atau yang lebih dikenal dengan 4G, yang saat ini masih menjadi andalan para pengguna jaringan telekomunikasi yang membutuhkan akses data cepat. Hal ini menyebabkan bertambahnya pengguna LTE. Coverage jaringan LTE di Jakarta sudah mencapai sekitar $84 \%$ [1]. Jakarta yang didominasi daerah perkantoran dan padat penduduk, terlebih dibeberapa pemukiman yang berdekatan dengan area perkantoran seringkali tidak mendapat layanan yang baik. Salah satu contoh adalah di Jl. Karet Gusuran 3 yang berada di daerah Karet Kuningan, seringkali pengguna jaringan mengeluhkan buruk nya sinyal LTE yang diterima dan berdampak pada lambat nya akses data di daerah tersebut dan mengganggu aktifitas dalam komunikasi maupun bisnis. Untuk memperbaiki kualitas jaringan di daerah tersebut perlu dilakukanya optimasi terhadap jaringan LTE didaerah tersebut.

Untuk meningkatkan kualitas jaringan LTE dapat dilakukan optimasi dengan beberapa metode. Pada penelitian sebelumnya [2] dilakukan optimasi pada jaringan 3G menggunakan repeater di PT SICPA PERURI SEKURINK, hasil yang didapatkan parameter RSCP, RSSI, dan Ec/No menjadi lebih baik dibandingkan sebelum adanya pemasangan repeater. Lalu pada penelitian [3] dilakukan optimasi dengan algoritma genetika, didapatkan hasil algoritma genetika mampu memberikan solusi yang cukup baik untuk penentuan posisi BTS, namun untuk posisi BTS baru diperlukan proses yang tidak mudah dan memakan waktu lama. Pada penelitian [4] optimasi didaerah suburban Cigadung dengan melakukan reazimuth antena, didapati nilai RSRP yang awalnya $-110 \mathrm{dBm}$ menjadi $-92.3 \mathrm{dBm}$, nilai SINR dari $-5 \mathrm{~dB}$ menjadi $13.5 \mathrm{~dB}$, dan nilai troughput meningkat dari $512 \mathrm{kbps}$ menjadi $14 \mathrm{Mbps}$. Pada penelitian [5] dilakukan optimasi jaringan indoor dengan beberapa metode dan didapatkan hasil yang efektif adalah dengan melakukan pemasangan IBC, yaitu melakukan penambahan kapasitas rill, karena dilakukan seperti pemasangan site baru. Dan pada penelitian [6] dilakukan optimasi di daerah Tanjakan Mauk, Tangerang dengan metode Physical Tuning, didapatkan hasil peningkatan RSRP dalam presentase dari 76,12\% menjadi 92,94\%, sedangkan SINR meningkat dalam presentase dari 91,79\% menjadi 95,35\%.

Dari hasil beberapa penelitian diatas, pada penelitian ini dilakukan optimasi jaringan LTE pada frekuensi $1800 \mathrm{MHz}$ di daerah Karet Kuningan dengan menggunakan salah satu jenis dari metode physical tuning yaitu electrical tilt. Diperlukan pengecekan parameter dari site-site sekitar lokasi yang kemungkinan mengcover area tersebut, setelah itu dilakukan simulasi dengan memasukan parameter dari site yang dominan mengcover area tersebut, dan melakukan electrical tilt.

\section{METODE PENELITIAN}

Metode yang dilakukan dalam penelitian ini yaitu pengumpulan parameter awal dari site di sekitar lokasi meliputi jenis antena, ketinggian antena, pola radiasi antena dan pengaturan daya pancar antena. Pada penelitian ini dilakukan dua kali simulasi jaringan LTE dengan menggunakan Atoll, pertama dengan menggunakan parameter existing dan kedua dengan menggunakan parameter hasil perhitungan untuk optimasi. Setelah kedua simulasi dilakukan akan dibandingkan nilai dari Signal level atau pada jaringan LTE disebut dengan RSRP (Reference Signal Received Power). Simulasi berfungsi untuk mengetahui keadaan awal jaringan berdasarkan parameter yang ada. Hasil simulasi dapat menentukan sektor yang dapat di optimasi untuk meningkatkan kualitas jaringan. Diagram alir metode penelitian diperlihatkan pada gambar 1. 


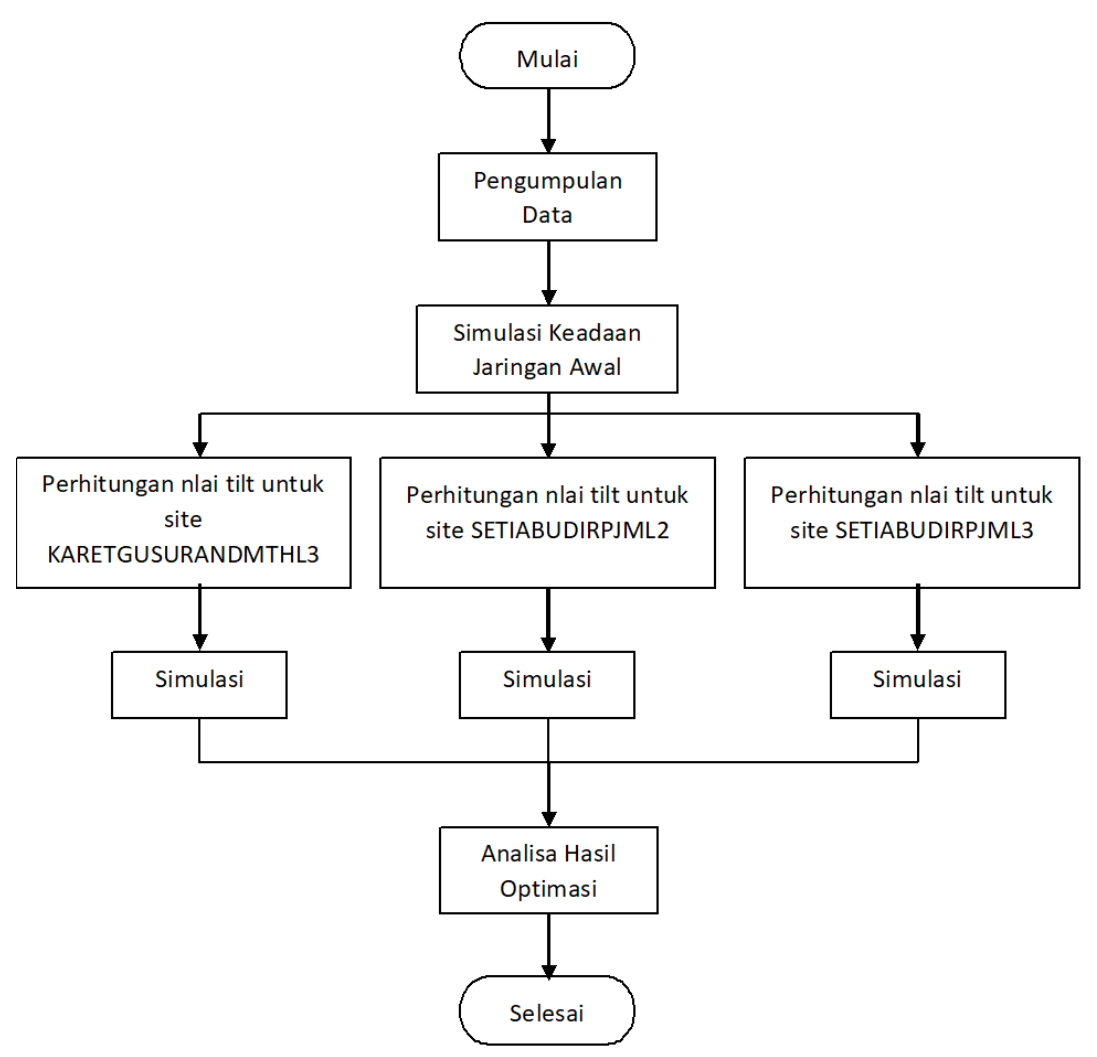

Gambar 1 Diagram alir penelitian

\subsection{Lokasi Penelitian}

Daerah yang menjadi target penelitian adalah daerah yang dilaporkan memiliki kualitas jaringan yang buruk yaitu Jl. Karet Gusuran III yang berada di daerah Karet Kuningan Jakarta Selatan. Objek penelitian kali ini adalah site KARETGUSURANDMTHL dan SETIABUDIRPJML. Lokasi penelitian merupakan daerah Urban yaitu daerah di pusat kota dikelilingi oleh gedung-gedung tinggi dan pemukiman padat.

\subsection{Spesifikasi dan Parameter Site}

Spesifikasi dan parameter site dibutuhkan untuk melakukan simulasi keadaan awal jaringan. Pada tabel 1 memperlihatkan spesifikasi dan parameter dari site-site yang termasuk di coverage area.

Tabel 1 Parameter dan spesifikasi site [7]

\begin{tabular}{|c|c|c|c|c|c|}
\hline LTE Sitename & Cellname & Azimuth & E-DownTilt & M-DownTilt & Height \\
\hline KARETGUSURANDMTHL & KARETGUSURANDMTHL1 & 130 & 8 & 1 & 17 \\
\hline KARETGUSURANDMTHL & KARETGUSURANDMTHL2 & 230 & 7 & 1 & 17 \\
\hline KARETGUSURANDMTHL & KARETGUSURANDMTHL3 & 330 & 8 & 1 & 17 \\
\hline SETIABUDIRPJML & SETIABUDIRPJML1 & 90 & 4 & 0 & 9 \\
\hline SETIABUDIRPJML & SETIABUDIRPJML2 & 300 & 4 & 0 & 9 \\
\hline SETIABUDIRPJML & SETIABUDIRPJML3 & 270 & 4 & 0 & 17 \\
\hline WISMATAMARASTPHL & WISMATAMARASTPHL1 & 40 & 3 & 2 & 12 \\
\hline WISMATAMARASTPHL & WISMATAMARASTPHL2 & 240 & 3 & 2 & 12 \\
\hline
\end{tabular}


Pada penelitian ini digunakan parameter pada tabel 1 untuk proses simulasi keadaan jaringan existing pada lokasi penelitian sebelum dilakukan optimasi.

\subsection{Parameter Jaringan LTE}

Pada penelitian ini, digunakan 4 parameter jaringan LTE, yaitu:

\section{RSRP (Reference Signal Received Power)}

RSRP merupakan parameter untuk sinyal power jaringan LTE yang diterima oleh user dalam frekuensi tertentu yang mengindikasi kan semakin jauh jarak antara site dengan user maka nilai RSRP yang diterima oleh user menjadi semakin kecil. Pada tabel 2 ditunjukan range nilai RSRP yang menjadi acuan pengukuran pada penelitian ini. Range nilai ini berdasarkan ketentuan yang ada pada software Atoll Rsrp Range.

Tabel 2 Range nilai RSRP

\begin{tabular}{|l|c|c|}
\hline \multicolumn{1}{|c|}{ RSRP Range } & Color & Note \\
\hline more than $-70 \mathrm{dBm}$ & & \multirow{2}{*}{ Excellent } \\
\hline$-71 \mathrm{dBm}$ to $-75 \mathrm{dBm}$ & & \multirow{2}{*}{ Good } \\
\hline$-76 \mathrm{dBm}$ to $-80 \mathrm{dBm}$ & & \multirow{2}{*}{ Fair } \\
\hline$-81 \mathrm{dBm}$ to $-85 \mathrm{dBm}$ & & \multirow{2}{*}{ Poor } \\
\hline$-86 \mathrm{dBm}$ to $-90 \mathrm{dBm}$ & & \\
\hline$-91 \mathrm{dBm}$ to $-95 \mathrm{dBm}$ & & \\
\hline$-96 \mathrm{dBm}$ to $-100 \mathrm{dBm}$ & & \\
\hline$-101 \mathrm{dBm}$ to $-105 \mathrm{dBm}$ & & \\
\hline
\end{tabular}

\section{SINR (Signal to Interference Ratio)}

SINR adalah rasio perbandingan antara sinyal yang dipancarkan dengan interferensi maupun noise yang timbul dan mempengaruhi sinyal utama. Nilai SINR dibutuhkan untuk mengetahui jumlah interferensi, pengukuran SINR sangat penting dilakukan untuk menghindari kegagalan penerimaan layanan antara eNodeB dengan UE. Pada tabel 3 ditunjukan range nilai SINR yang menjadi acuan pengukuran pada penelitian ini. Range nilai ini berdasarkan ketentuan yang ada pada software Atoll Rsrp Range.

Tabel 3 Range nilai SINR

\begin{tabular}{|c|c|}
\hline SINR & Keterangan \\
\hline$-20 \mathrm{~dB}$ to $-10 \mathrm{~dB}$ & Very Bad \\
\hline$-10 \mathrm{~dB}$ to $0 \mathrm{~dB}$ & Bad \\
\hline $0 \mathrm{~dB}$ to $10 \mathrm{~dB}$ & Good \\
\hline $10 \mathrm{~dB}$ to $20 \mathrm{~dB}$ & Excellent \\
\hline
\end{tabular}

\section{RSRQ (Reference Signal Received Quality)}

RSRQ merupakan parameter yang menentukan kualitas dari sinyal yang diterima. RSRQ juga membantu sistem dalam proses handover, dengan cara mengurutkan kualitas kandidat sel tujuan handover. Pada tabel 4 ditunjukan range nilai RSRQ yang menjadi acuan pengukuran pada penelitian ini. Range nilai ini berdasarkan ketentuan yang ada pada software Atoll Rsrp Range.

Tabel 4 Range nilai RSRQ

\begin{tabular}{|c|c|}
\hline RSRQ & Keterangan \\
\hline$>=1 \mathrm{~dB}$ & Excellent \\
\hline $1 \mathrm{~dB}$ to $-5 \mathrm{~dB}$ & Good \\
\hline$-5 \mathrm{~dB}$ to $-8 \mathrm{~dB}$ & Normal \\
\hline$-8 \mathrm{~dB}$ to $-12 \mathrm{~dB}$ & Poor \\
\hline$<=-12 \mathrm{~dB}$ & Bad \\
\hline
\end{tabular}


4. Throughput

Throughput merupakan besarnya jumlah paket yang sukses diterima user dan dibagi waktu pengiriman paket. Pada Tabel 5 ditunjukan range dari throughput. Range nilai ini berdasarkan ketentuan yang ada pada software Atoll Rsrp Range.

Tabel 5 Range nilai Throughput

\begin{tabular}{|l|l|}
\hline Throughput & Keterangan \\
\hline$>-20 \mathrm{Mbps}$ & Excellent \\
\hline $10 \mathrm{Mbps}$ to $20 \mathrm{Mbps}$ & Good \\
\hline $1 \mathrm{Mbps}$ to $10 \mathrm{Mbps}$ & Normal \\
\hline $0.5 \mathrm{Mbps}$ to $1 \mathrm{Mbps}$ & Fair \\
\hline$<=0.5 \mathrm{Mbps}$ & Poor \\
\hline
\end{tabular}

\section{$2.4 \quad$ Pengukuran Antenna Tilting}

Tilting dilakukan untuk mengurangi coverage pada area tertentu, sehingga antena hanya melayani area yang sesuai dengan rancangan awal nya. Pada gambar 2 dapat dilihat ilustrasi pengukuran antenna tilting.

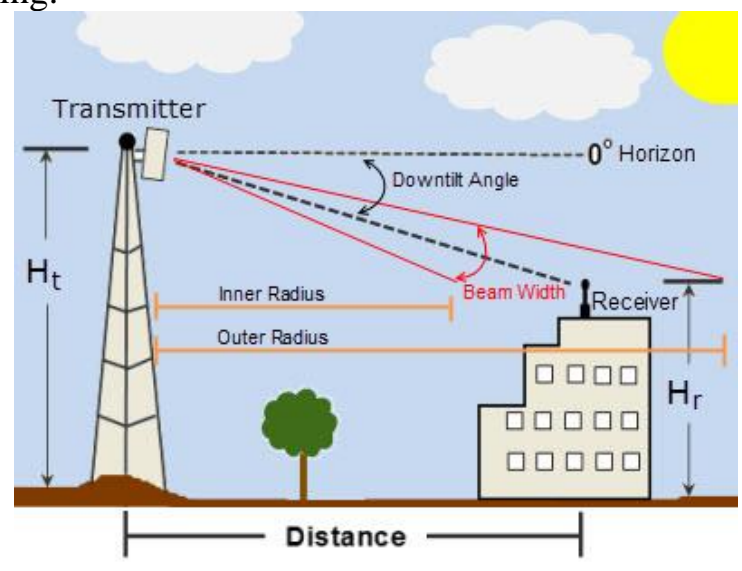

Gambar 2 Antenna tilting [8]

Keterangan gambar :

$\mathrm{Ht} \quad=$ Tinggi antena transmitter $(\mathrm{m})$

$\mathrm{Hr} \quad=$ Tinggi antena receiver $(\mathrm{m})$

Angle $\quad=$ Sudut tilt antena

Beamwidth $=$ Sudut lebar vertical beamwidth dari antena $\left({ }^{\circ}\right)$

Distance $\quad=$ Jarak antara transmitter dan receiver

Inner radius $\quad=$ Radius dalam dari daya pancar antena

Outer radius $\quad=$ Radius luar dari daya pancar antena

Untuk inner radius dan outer radius dapat dicari dengan persamaan berikut :

Inner Radius $=\frac{H t-H r}{\tan \left(A+\frac{B W}{2}\right)}[6]$

Outer Radius $=\frac{(H t-H r)}{\tan \left(A-\frac{B W}{2}\right)}[6]$

Untuk tilting ditunjukan dengan persamaan sebagai berikut :

$A_{d t}=\tan ^{-1}\left(\frac{H t-H r}{\text { Distance }(m)}\right)+\frac{B w}{2}[6]$ 
Keterangan :

$\mathrm{A}_{\mathrm{dt}} \quad=$ Antenna downtilt

$\mathrm{Ht} \quad=$ Tinggi antena transmitter

$\mathrm{Hr}=$ Tinggi antena receiver

$\mathrm{Bw} \quad=$ Beamwidth antena

\section{HASIL DAN PEMBAHASAN}

\subsection{Data Existing}

Dengan menggunakan parameter dan spesifikasi site dilakukan simulasi jaringan existing dengan menggunakan software Atoll.

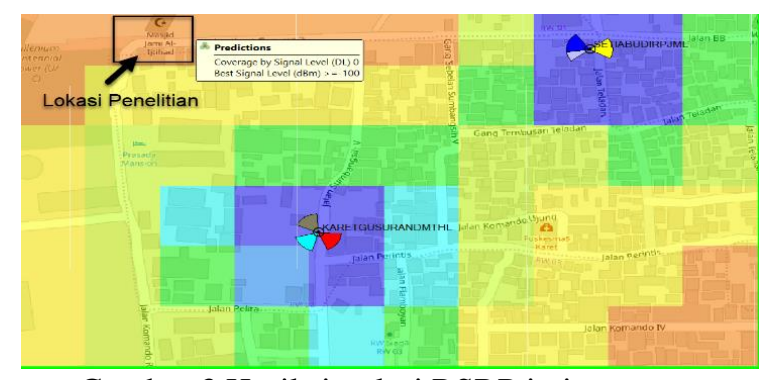

Gambar 3 Hasil simulasi RSRP jaringan existing

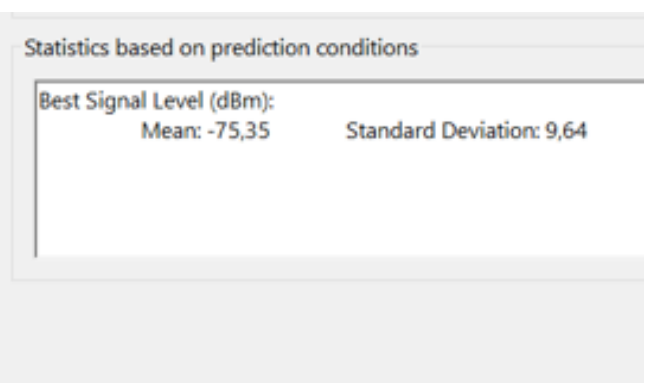

Gambar 4 Nilai mean RSRP jaringan exisiting

RSRP jaringan existing berada dalam kategori poor ditandai dengan warna jingga pada gambar 3. Berdasarkan tabel 2, nilai RSRP berada pada -96 dBm sampai -100 dBm. Dengan nilai mean $-75,35 \mathrm{dBm}$ seperti yang terlihat pada gambar 4 .

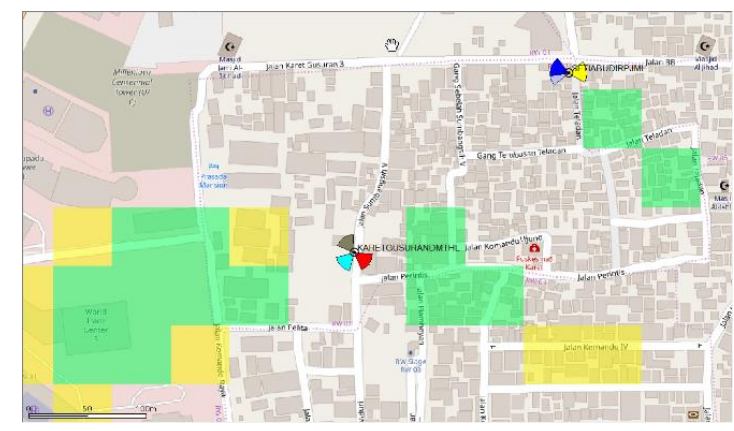

Gambar 5 Hasil simulasi SINR jaringan existing

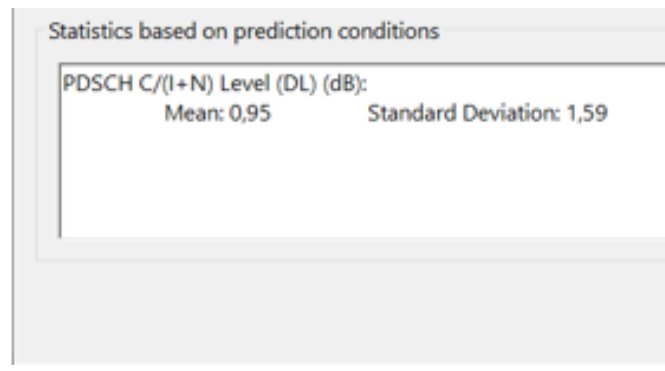

Gambar 6 Nilai mean SINR jaringan existing

Dari hasil simulasi jaringan existing, didapatkan nilai mean SINR di lokasi penelitian sebesar $-0,95 \mathrm{~dB}$. Berdasarkan tabel 3, nilai ini masih berada di kategori good.

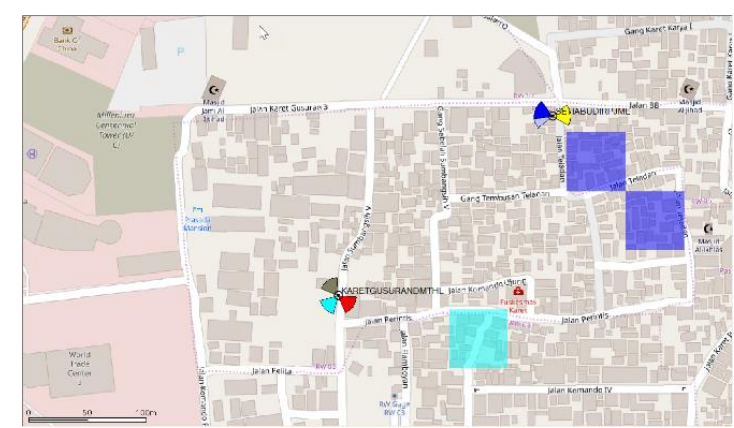

Gambar 7. Hasil simulasi RSRQ jaringan existing

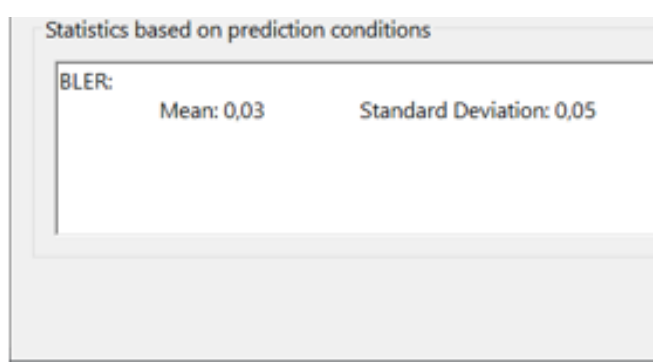

Gambar 8. Nilai mean RSRQ jaringan existing 
Nilai mean RSRQ jaringan existing yang didapat dari hasil simulasi sebesar $0.03 \mathrm{~dB}$, yang masih berada dalam kategori good berdasarkan tabel 4 .

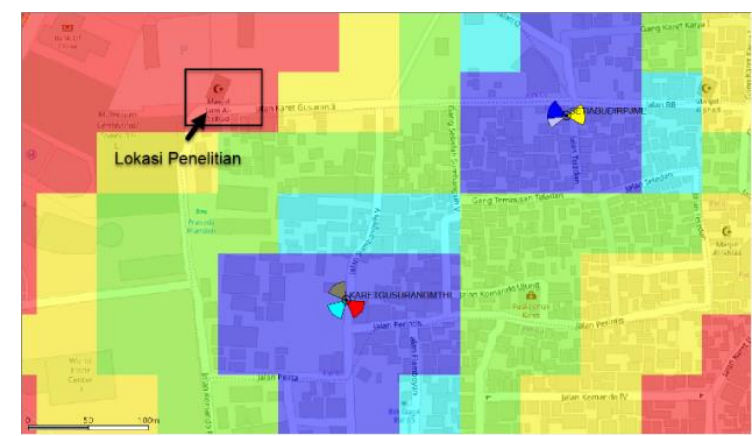

Gambar 9. Hasil simulasi Throughput jaringan existing

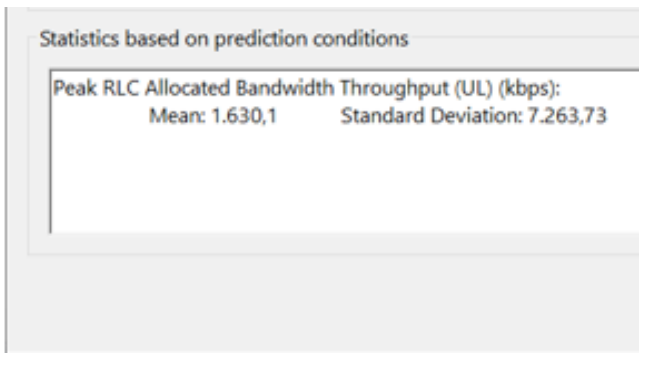

Gambar 10 Nilai mean Throughput jaringan existing

Dari simulasi jaringan existing yang ditunjukan lokasi penelitian mendapatkan hasil throughput merah, mengacu pada Tabel 5 warna merah menunjukan kecepatan kurang dari 0.5 Mbps. Dan nilai mean untuk throughput sebesar 1.6 Mbps.

\subsection{Proses Optimasi}

Proses optimasi akan dilakukan pada sektor berikut :

1. Sektor 3 pada site KARETGUSURANDMTHL

2. Sektor 2 pada site SETIABUDIRPJML

3. Sektor 3 pada site SETIABUDIRPJML

\subsubsection{Optimasi site KARETGUSURANDMTHL Sektor 3}

\section{Perhitungan Nilai Tilt}

Sektor 3 site KARETGUSURANDMTHL memiliki ketinggian antena 17 meter, beamwidth sebesar $5.8^{\circ}$, dengan jarak antara site ke lokasi penelitian sekitar 209 meter.

$$
\begin{gathered}
A_{d t}=\tan ^{-1}\left(\frac{17-1}{209}\right)+\frac{5.8^{\circ}}{2} \\
A_{d t}=\tan ^{-1}\left(\frac{16}{209}\right)+2.9^{\circ} \\
A_{d t}=\tan ^{-1}(0.077)+2.9^{\circ} \\
A_{d t}=7.3^{\circ}
\end{gathered}
$$




\section{Simulasi Electrical Tilt}

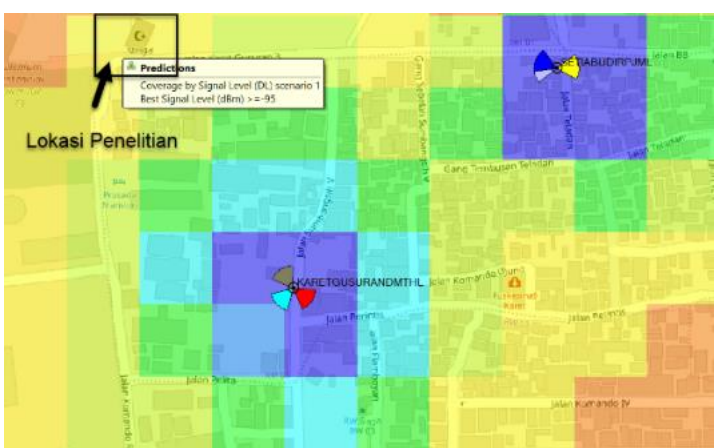

Gambar 11. Hasil simulasi RSRP dari optimasi site KARETGUSURANDMTHL sektor 3

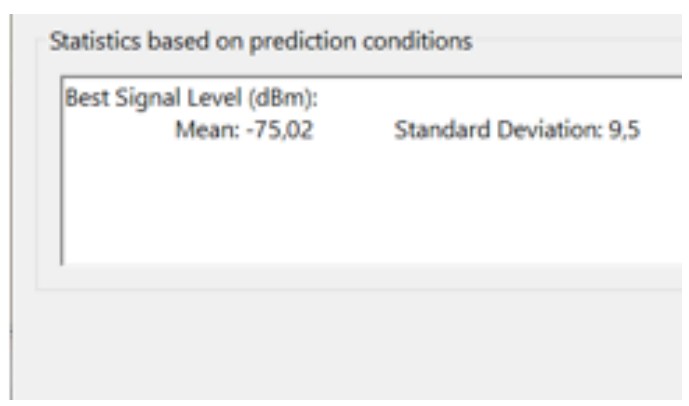

Gambar 12. Nilai mean RSRP dari optimasi site KARETGUSURANDMTHL sektor 3

Dari hasil simulasi RSRP yang di terima di lokasi ditunjukan dengan warna kuning, berdasarkan tabel 2 nilai RSRP nya berada diantara $-91 \mathrm{dBm}$ sampai $-95 \mathrm{dBm}$ dan berada di kategori Fair. Dengan nilai mean RSRP sebesar -75,02 dBm.

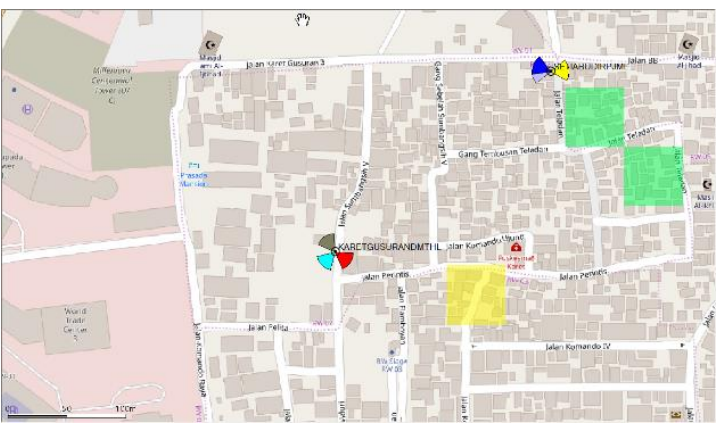

Gambar 13 Hasil simulasi SINR dari optimasi site KARETGUSURANDMTHL sektor 3

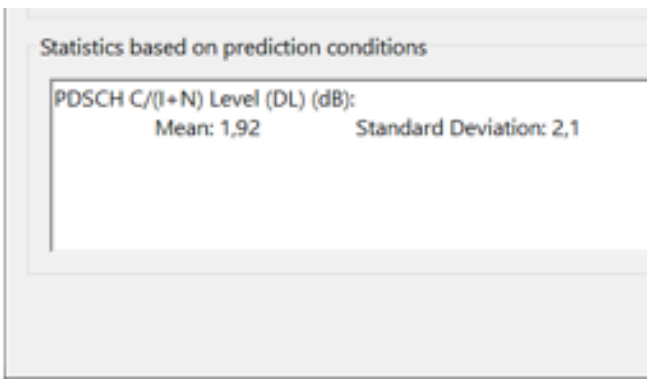

Gambar 14 Nilai mean SINR dari optimasi site KARETGUSURANDMTHL sektor 3

Nilai mean SINR yang didapat di lokasi penelitian adalah sebesar 1,92 dB. Nilai ini masih berada dalam kategori good berdasarkan tabel 3 .

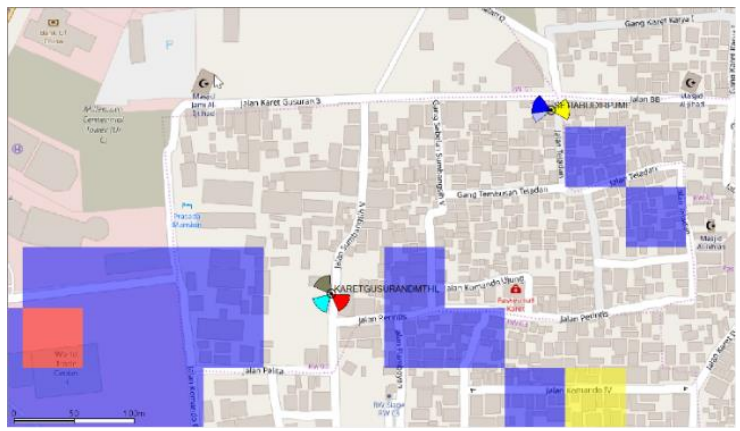

Gambar 15 Hasil simulasi RSRQ dari optimasi site KARETGUSURANDMTHL sektor 3

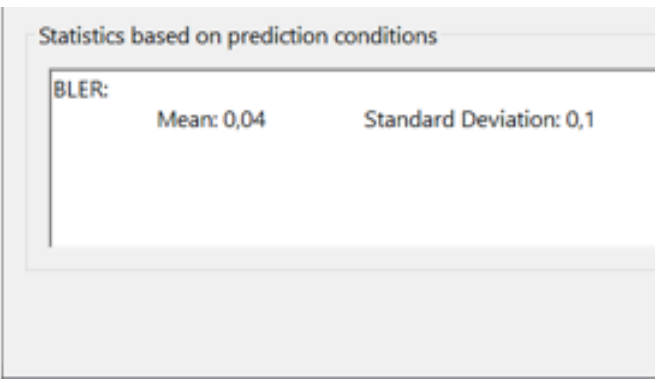

Gambar 16 Nilai mean RSRQ dari optimasi site KARETGUSURANDMTHL sektor 3

Nilai mean RSRQ dari simulasi mendapatkan nilai sebesar $0,04 \mathrm{~dB}$ dan masih dalam kategori good berdasarkan tabel 4. 


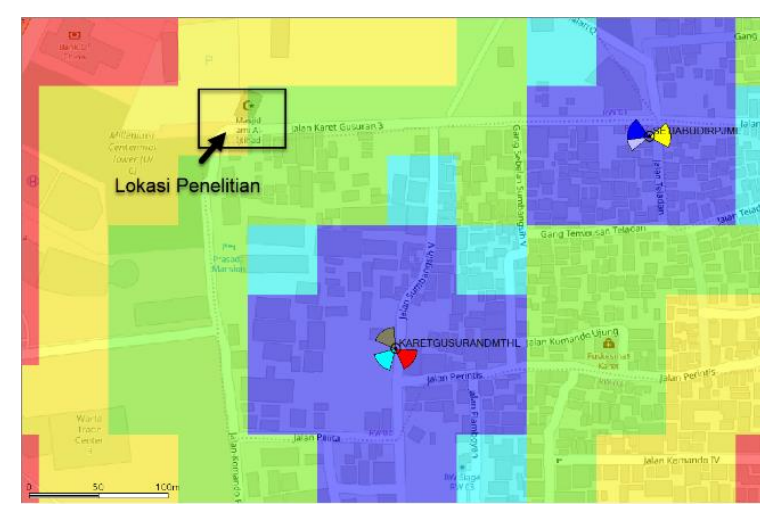

Gambar 17 Hasil simulasi throughput dari optimasi site KARETGUSURANDMTHL sektor 3

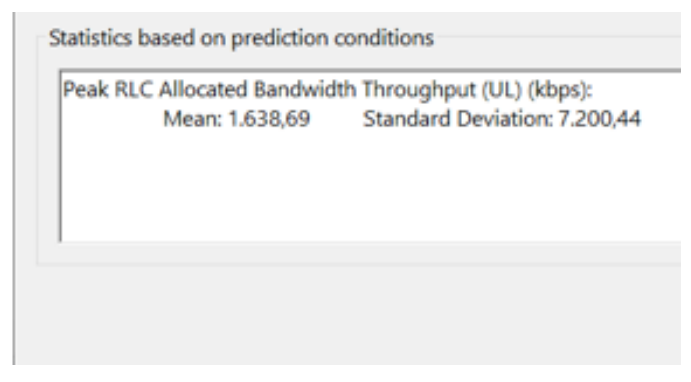

Gambar 18 Nilai mean thorughput dari optimasi site KARETGUSURANDMTHL sektor 3

Nilai throughput yang didapat di lokasi berwarna kuning dan hijau, dengan nilai $1 \mathrm{Mbps}$ sampai dengan 10 Mbps. Dan nilai mean sebesar $1.638 \mathrm{kbps}$. Berdasarkan tabel 5 nilai ini berada pada kategori normal.

\subsubsection{Optimasi site SETIABUDIRPJML sektor 2}

1. Perhitungan Nilai Tilt

Sektor 2 site SETIABUDIRPJML memiliki ketinggian antena 9 meter, beamwidth sebesar $7^{\circ}$, dengan jarak antara site ke lokasi penelitian sekitar 297 meter.

$$
\begin{gathered}
A_{d t}=\tan ^{-1}\left(\frac{9-1}{297}\right)+\frac{7^{\circ}}{2} \\
A_{d t}=\tan ^{-1}\left(\frac{8}{297}\right)+3.5^{\circ} \\
A_{d t}=\tan ^{-1}(0.026)+3.5^{\circ} \\
A_{d t}=4.98^{\circ}
\end{gathered}
$$

2. Simulasi Electrical Tilt

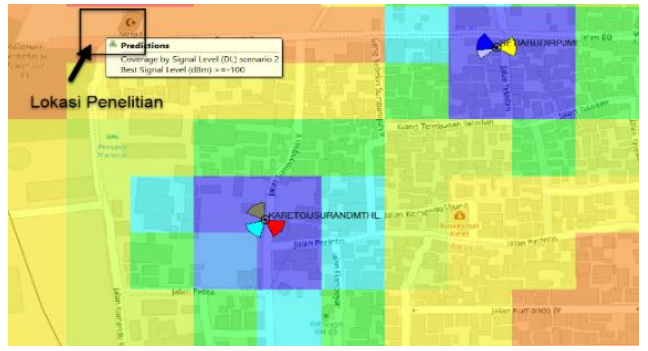

Gambar 19 Hasil simulasi RSRP dari optimasi site SETIABUDIRPJML sektor 2

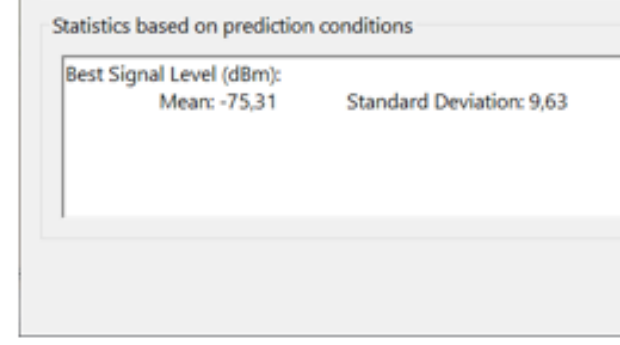

Gambar 20 Nilai mean RSRP dari optimasi site SETIABUDIRPJML sektor 2

Nilai RSRP yang diterima pada lokasi penelitian ditunjukan dengan warna jingga, dengan nilai sebesar $-96 \mathrm{dBm}$ sampai dengan $-100 \mathrm{dBm}$, berdasarkan tabel 2 nilai ini berada di dalam kategori poor dengan nilai mean sebesar $-75,31 \mathrm{dBm}$. 


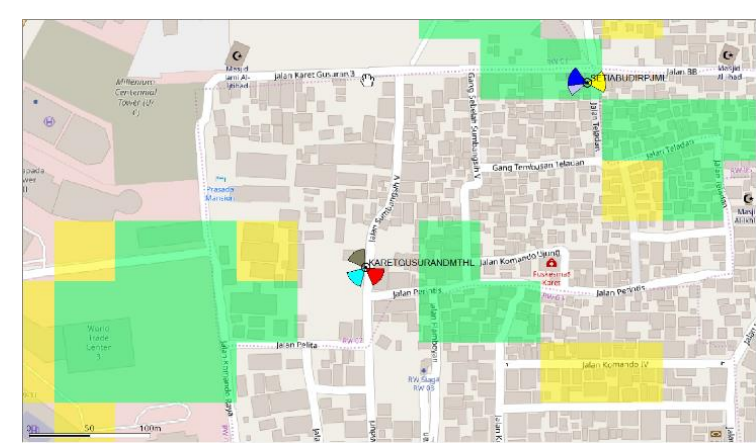

Gambar 21 Hasil simulasi SINR dari optimasi site SETIABUDIRPJML sektor 2

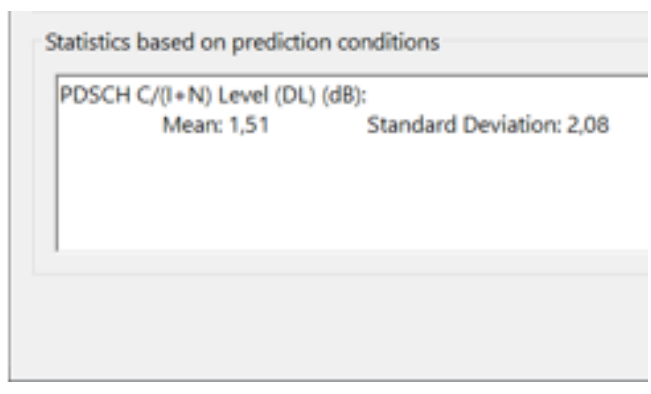

Gambar 22 Nilai mean SINR dari optimasi site SETIABUDIRPJML sektor 2

Nilai mean SINR dari hasil optimasi sebesar $1.51 \mathrm{~dB}$. Berdasarkan tabel 3, nilai ini masih termasuk kategori good.
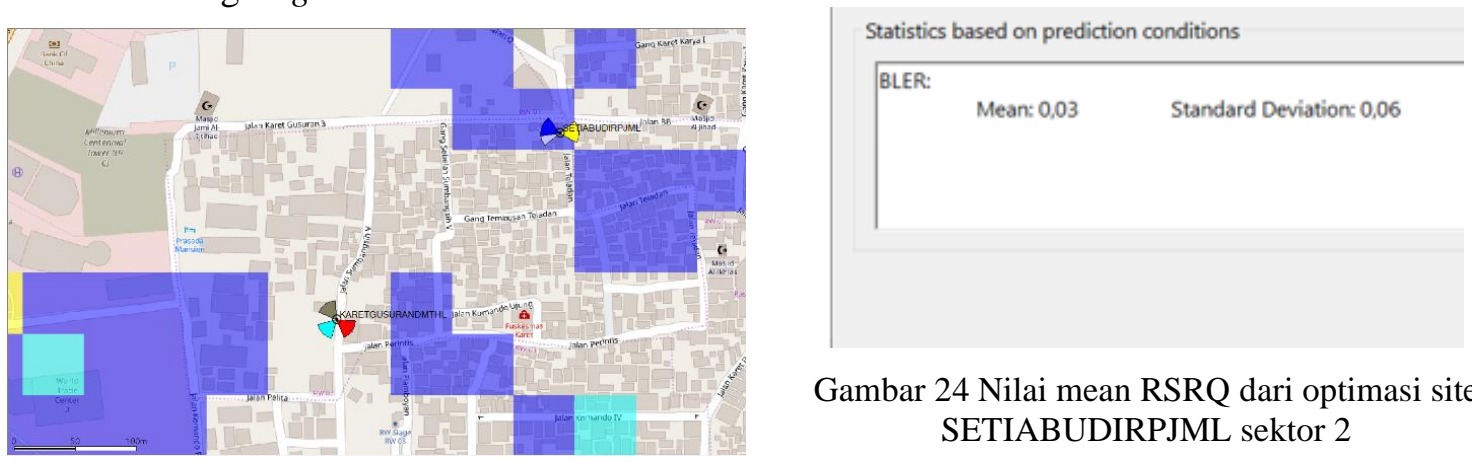

Gambar 24 Nilai mean RSRQ dari optimasi site SETIABUDIRPJML sektor 2

Gambar 23 Hasil simulasi RSRQ dari optimasi site SETIABUDIRPJML sektor 2

Hasil dari simulasi RSRQ untuk optimasi mendapatkan nilai $0.03 \mathrm{~dB}$. Nilai termasuk dalam kategori normal berdasarkan tabel 4 .

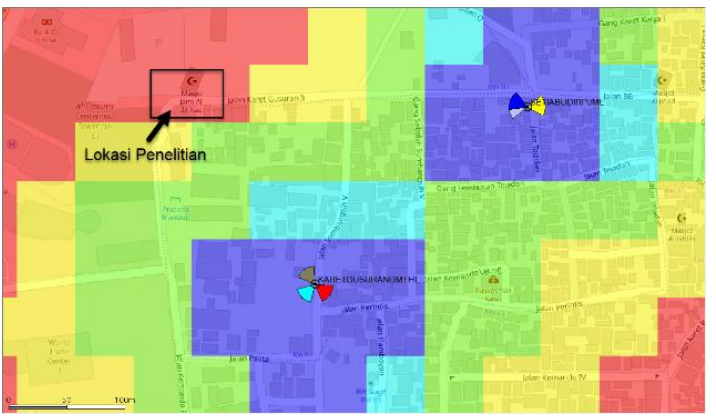

Gambar 25 Hasil simulasi Throughput dari optimasi site SETIABUDIRPJML sektor 2

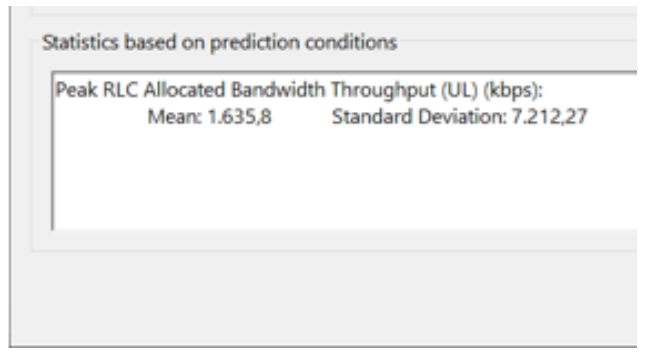

Gambar 26 Nilai mean Throughput dari optimasi site SETIABUDIRPJML sektor 2

Nilai Throughput yang didapat di lokasi berwarna merah, dengan nilai dibawah dibawah 512 kpbs berdasarkan Tabel 5, dan berada dalam kategori Poor.

\subsubsection{Optimasi site SETIABUDIRPJML sektor 3}

\section{Perhitungan Nilai Tilt}

Sektor 3 site SETIABUDIRPJML memiliki ketinggian antena 17 meter, beamwidth sebesar $7^{\circ}$, dengan jarak antara site ke lokasi penelitian sekitar 297 meter. 


$$
\begin{gathered}
A_{d t}=\tan ^{-1}\left(\frac{17-1}{297}\right)+\frac{7^{\circ}}{2} \\
A_{d t}=\tan ^{-1}\left(\frac{16}{297}\right)+3.5^{\circ} \\
A_{d t}=\tan ^{-1}(0.053)+3.5^{\circ} \\
A_{d t}=6.53^{\circ}
\end{gathered}
$$

2. Simulasi Electrical Tilt

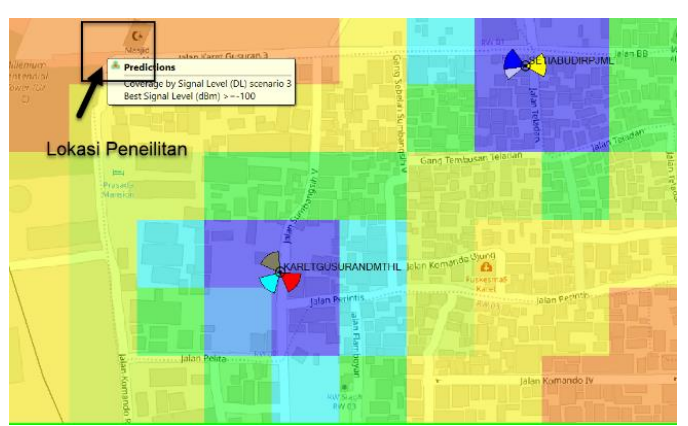

Gambar 27 Hasil simulasi RSRP dari optimasi site SETIABUDIRPJML sektor 3

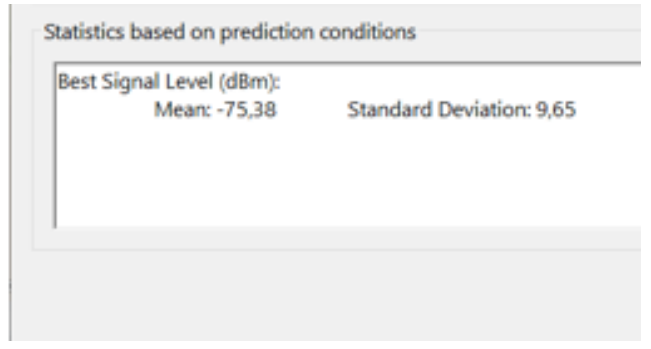

Gambar 28. Nilai mean RSRP dari optimasi site SETIABUDIRPJML sektor 3

Dari hasil simulasi RSRP yang diterima dilokasi ditunjukan dengan warna jingga, berdasarkan Tabel 2 nilai RSRP nya berada diantara $-96 \mathrm{dBm}$ sampai $-100 \mathrm{dBm}$ dan berada di kategori Poor. Dengan nilai mean RSRP sebesar -75,38 dBm.

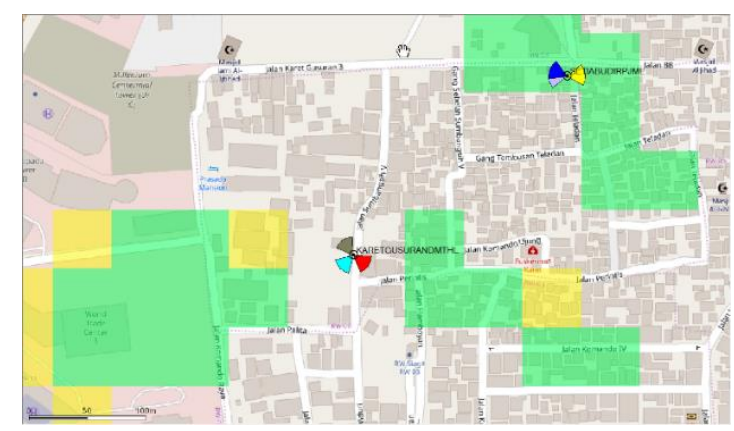

Gambar 29 Hasil simulasi SINR dari optimasi site SETIABUDIRPJML sektor 3

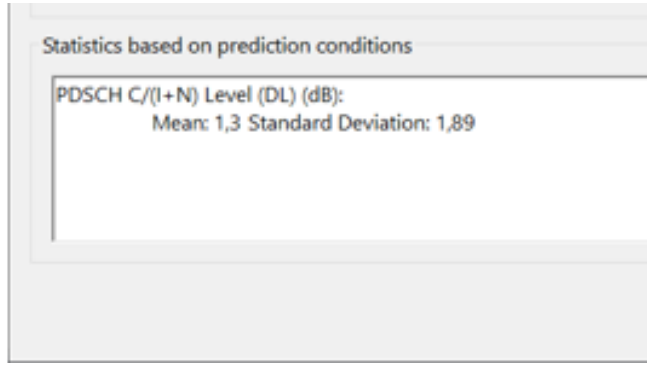

Gambar 30 Nilai mean SINR dari optimasi site SETIABUDIRPJML sektor 3

Nilai mean SINR yang didapat di lokasi penelitian adalah sebesar 1,89 dB. Nilai ini masih berada dalam kategori Good berdasarkan Tabel 3.

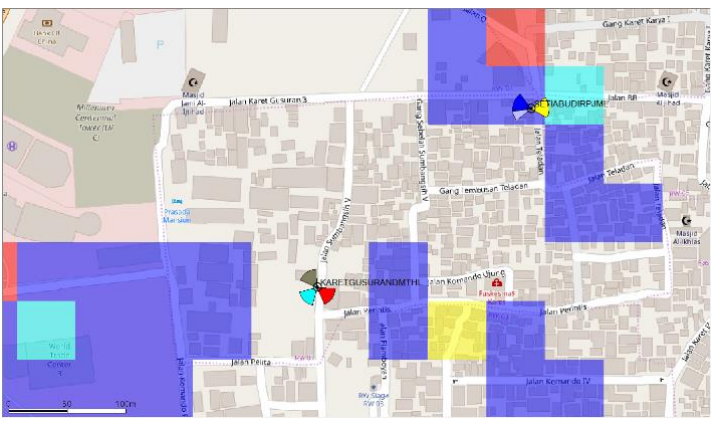

Gambar 31 Hasil simulasi RSRQ dari optimasi site SETIABUDIRPJML sektor 3

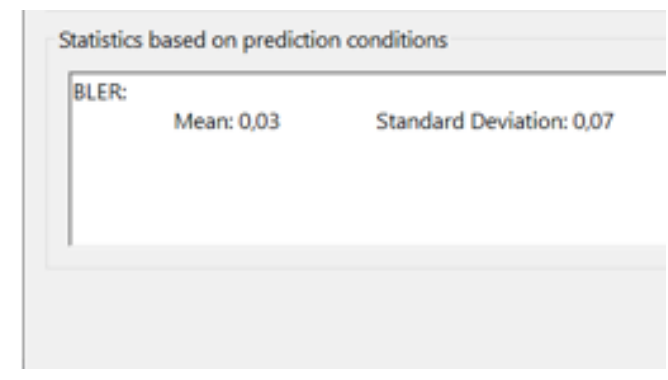

Gambar 32 Nilai mean RSRQ dari optimasi site SETIABUDIRPJML sektor 3 
Pada Gambar 32 dapat dilihat nilai RSRQ dari simulasi optimasi site SETIABUDIRPJML sektor 3 sebesar $0.03 \mathrm{~dB}$. Berdasarkan Tabel 4 nilai ini masih dalam kategori Normal.

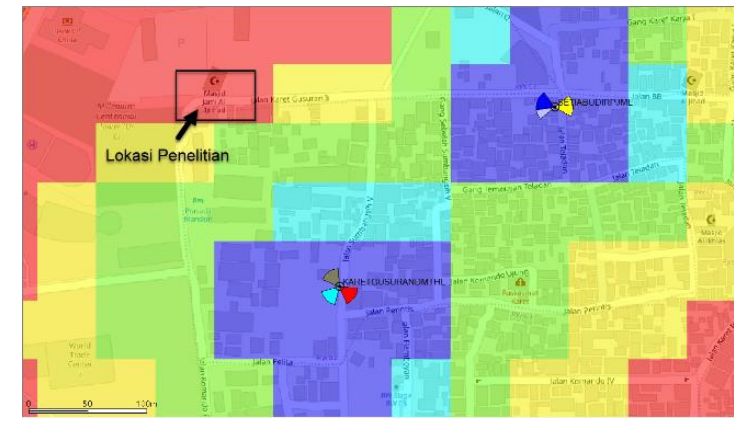

Gambar 33 Hasil simulasi Throughput dari optimasi site SETIABUDIRPJML sektor 3

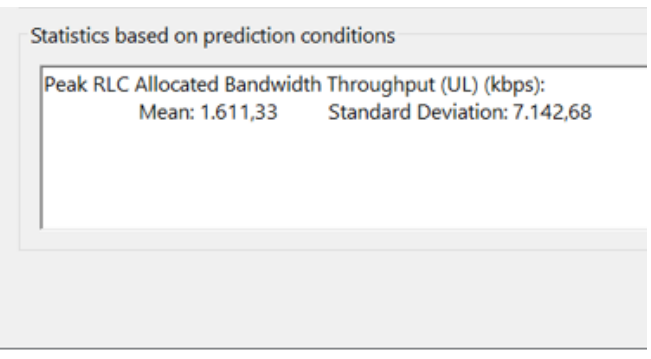

Gambar 34 Nilai mean Throughput dari optimasi site SETIABUDIRPJML sektor 3

Nilai Throughput yang didapat di lokasi berwarna merah, dengan nilai dibawah dibawah 512 kpbs berdasarkan Tabel 5, dan berada dalam kategori Poor.

a. Analisa Hasil Optimasi

\subsubsection{RSRP}

Tabel 6. Analisa RSRP dari hasil optimasi

\begin{tabular}{|c|c|c|c|c|c|c|}
\hline \multirow{2}{*}{ Sektor } & \multicolumn{2}{|c|}{$\operatorname{RSRP}(\mathrm{dBm})$} & \multirow{2}{*}{ Keterangan } & \multicolumn{2}{c|}{ Mean RSRP $(\mathrm{dBm})$} & \multirow{2}{*}{ Keterangan } \\
\cline { 2 - 3 } \cline { 5 - 7 } & Sebelum & Sesudah & & Sebelum & Sesudah & \\
\hline KARETGUSURANDMTHL3 & -100 & -95 & Meningkat & $-75,35$ & $-75,02$ & Meningkat $-0,33$ \\
\hline SETIABUDIRPJML2 & -100 & -100 & Tetap & $-75,35$ & $-75,31$ & Meningkat $-0,04$ \\
\hline SETIABUDIRPJML3 & -100 & -100 & Tetap & $-75,35$ & $-75,38$ & Menurun 0,03 \\
\hline
\end{tabular}

Dari Tabel 6, dilihat peningkatan nilai RSRP para optimasi dari site KARETGUSURANDMTHL sektor 3, peningkatan nilai RSRP sebesar $-5 \mathrm{dBm}$. Dan nilai mean mengalami peningkatan $-0,33 \mathrm{dBm}$.

i. $\quad$ SINR

Tabel 7. Analisa SINR dari hasil optimasi

\begin{tabular}{|c|c|c|c|}
\hline \multirow{2}{*}{ Sektor } & \multicolumn{2}{|c|}{ SINR $(\mathrm{dB})$} & Keterangan \\
\cline { 2 - 4 } & Sebelum & Sesudah & \\
\hline KARETGUSURANDMTHL3 & 0,95 & 1,92 & Meningkat 0,97 \\
\hline SETIABUDIRPJML2 & 0,95 & 1,51 & Meningkat 0,56 \\
\hline SETIABUDIRPJML3 & 0,95 & 1,3 & Meningkat 0,35 \\
\hline
\end{tabular}

Pada Tabel 7, dapat dilihat nilai SINR dari ketiga optimasi menunjukan peningkatan sebesar $0.97 \mathrm{~dB}$ dari nilai SINR existing. 
ii. $\quad R S R Q$

Tabel 8. Analisa RSRQ dari hasil optimasi

\begin{tabular}{|c|c|c|c|}
\hline \multirow{2}{*}{ Sektor } & \multicolumn{2}{|c|}{ RSRQ $(\mathrm{dB})$} & Keterangan \\
\cline { 2 - 4 } & Sebelum & Sesudah & \\
\hline KARETGUSURANDMTHL3 & 0,03 & 0,04 & Meningkat 0,01 \\
\hline SETIABUDIRPJML2 & 0,03 & 0,03 & Tetap \\
\hline SETIABUDIRPJML3 & 0,03 & 0,03 & Tetap \\
\hline
\end{tabular}

Dari Tabel 8, ditunjukan hasil simulasi RSRQ pada site KARETGUSURANDMTHL3 mengalami peningkatan sebesar $0.01 \mathrm{~dB}$ dari nilai RSRQ existing.

iii. Throughput

Tabel 9. Analisa Throughput dari hasil optimasi

\begin{tabular}{|c|c|c|c|c|c|c|}
\hline \multirow{2}{*}{ Sektor } & \multicolumn{2}{|c|}{ Throughput (kbps) } & \multirow{2}{*}{ Keterangan } & \multicolumn{2}{|c|}{ Mean Throughput (kbps) } & Keterangan \\
\cline { 2 - 7 } & Sebelum & Sesudah & & Sebelum & Sesudah & \\
\hline KARETGUSURANDMTHL3 & 512 & 1000 & Meningkat & 1630 & 1638 & Meningkat \\
\hline SETIABUDIRPJML2 & 512 & 512 & Tetap & 1630 & 1635 & Meningkat \\
\hline SETIABUDIRPJML3 & 512 & 512 & Tetap & 1630 & 1611 & Menurun \\
\hline
\end{tabular}

Pada Tabel 9, ditunjukan peningkatan pada optimasi site KARETGUSURANDMTHL sektor 3 ditunjukan peningkatan nilai throughput dari 512 kbps menjadi 1000 kbps.

Dari hasil dari simulasi, optimasi pada site KARETGUSURANDMTHL sektor 3 mengalami peningkatan di 4 parameter yang di gunakan. Dikarenakan site KARETGUSURANDMTHL memiliki jarak lebih dekat ke lokasi penelitian dengan jarak 209 meter. Sedangkan jarak site SETIABUDIRPJML ke lokasi penelitian sebesar 297 meter.

\section{KESIMPULAN}

Berdasarkan perhitungan, simulasi dan analisa pada penelitian ini, didapatkan kesimpulan sebagai berikut :

1. Berdasarkan simulasi jaringan existing, kualitas jaringan LTE di Jl. Karet Gusuran III, Karet Kuningan, Jakarta Selatan dapat dikatakan cukup buruk dikarenakan coverage dari site sekitar hanya melayani sebagian kecil dari daerah tersebut.

2. Metode electrical tilt cukup efisien dilakukan di lokasi penelitian, karena dapat dilakukan secara remote sehingga tidak perlu melakukan perubahan pada fisik antena, dan mudah untuk di adjust jika hasil optimasi belum bisa meningkatkan kualtas jaringan.

3. Dari hasil optimasi dan simulasi pada site KARETGUSURANDMTHL sektor 3, didapatkan peningkatan nilai RSRP sebesar $-5 \mathrm{dBm}$, dari sebelumnya $-100 \mathrm{dBm}$ menjadi $-95 \mathrm{dBm}$. Nilai SINR juga mangalami peningkatan sebesar $0.97 \mathrm{~dB}$, dari sebelumnya $0.95 \mathrm{~dB}$ menjadi 1.92 $\mathrm{dB}$. Peningkatan terjadi juga nilai RSRQ sebesar $0.01 \mathrm{~dB}$, dari sebelumnya $0.03 \mathrm{~dB}$ menjadi $0.04 \mathrm{~dB}$. Nilai throughput juga mengalami kenaikan dari sebelumnya $512 \mathrm{kbps}$ menjadi 1 Mbps sampai 10 Mbps.

4. Setelah hasil simulasi didapati pengaruh electrical tilt pada coverage adalah dapat meningkatkan dan menurunkan daya cakup antena.

\section{DAFTAR PUSTAKA}

[1] https://www.Liputan6.Com, "Lebih Dari 80 Persen Area Jakarta Diselimuti Jaringan 4g LTE,” 2020. https://www.liputan6.com/Tekno/Read/3627126/Lebih-Dari-80-PersenArea-Jakarta-Diselimuti-Jaringan-4g-Lte. (accessed Jan. 09, 2020).

[2] A. Widiyanto and R. Sirait, "PERANCANGAN PENGUATAN SINYAL INDOSAT 
MENGGUNAKAN REPEATER MICRO 3G REMOTEK DI PT. SICPA PERURI SEKURINK."

[3] G. E. Riani and W. F. Mahmudy, "Optimasi Jangkauan Jaringan 4G Menggunakan Algoritma Genetika," J. Teknol. Inf. dan Ilmu Komput., vol. 3, no. 2, pp. 141-146, 2016.

[4] I. Larasati, H. Hafidudin, and F. Rizkiatna, "Optimasi Jaringan Lte Di Area Cigadung Bandung," eProceedings Appl. Sci., vol. 3, no. 3, 2017.

[5] F. Maulana and P. W. Purnawan, "SIMULASI DAN KAJIAN PERBANDINGAN METODE OPTIMASI JARINGAN LTE (LONG TERM EVOLUTION) DENGAN PEMASANGAN REPEATER, PERENCANAAN IN BUILDING COVERAGE DAN UPGRADE CARRIER MODULE DI APARTEMEN SAINT MORITZ," Maest. Vol 2 No 1 Ed. April 2019, Apr. 2019, [Online]. Available: https://jom.ft.budiluhur.ac.id/index.php/maestro/article/view/171.

[6] A. N. Fajar and E. Devia, "Analisa Dan Optimalisasi Jaringan 4g Lte Dengan Metode Electrical Tilt Menggunakan Drivetest," JIIFOR (Jurnal Ilm. Inform. dan Komputer), vol. 1 , no. $1,2017$.

[7] H. N. T. for T. Project, “4G Engineering Parameter 20190708," Jabodetabek, 2019.

[8] https://www.pasternack.com/T-Calculator-Antenna-Downtilt.Aspx. (accessed Nov. 02, 2019). 